\title{
Profitability in Commercial Bank - A Case Study of Nepal
}

\author{
Anjay Kumar Mishra*, Deepak Raj Kandel ** \& P. S. Aithal*** \\ *Post Doctoral Research Scholar, Srinivas University, India and Associate Professor, Madan \\ Bhandari Memorial Academy Nepal, Urlabari3, Morang, Nepal \\ OrcidID: 0000-0003-2803-4918; Email: anjaymishra2000@ gmail.com \\ ** Visiting Faculty, Sanker Dev Campus, TU, Email; Kandeldeepak85@gmail.com \\ ****Professor, College of Management \& Commerce, Srinivas University, Mangalore, India \\ OrcidID: 0000-0002-4691-8736; E-mail: psaithal@ gmail.com
}

Area of the Paper: Business Management.

Type of the Paper: Analytical Business Research.

Type of Review: Peer Reviewed as per $|\mathrm{C}| \mathrm{O}|\mathrm{P}| \mathrm{E} \mid$ guidance.

Indexed In: OpenAIRE.

DOI: http://doi.org/10.5281/zenodo.4752052

Google Scholar Citation: IJCSBE

\section{How to Cite this Paper:}

Mishra, Anjay Kumar, Kandel, Deepak Raj, \& Aithal, P. S., (2021). Profitability in Commercial Bank - A Case from Nepal. International Journal of Case Studies in Business, IT, and Education (IJCSBE), 5(1), 61-77. DOI: http://doi.org/10.5281/zenodo.4752052.

International Journal of Case Studies in Business, IT and Education (IJCSBE)

A Refereed International Journal of Srinivas University, India.

Crossref DOI : https://doi.org/10.47992/IJCSBE.2581.6942.0101

(C) With Authors.

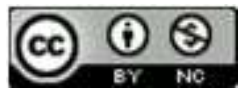

This work is licensed under a Creative Commons Attribution Non-Commercial 4.0 International License subject to proper citation to the publication source of the work.

Disclaimer: The scholarly papers as reviewed and published by the Srinivas Publications (S.P.), India are the views and opinions of their respective authors and are not the views or opinions of the S.P. The S.P. disclaims of any harm or loss caused due to the published content to any party. 


\title{
Profitability in Commercial Bank - A Case from Nepal
}

\author{
Anjay Kumar Mishra*, Deepak Raj Kandel ** \& P. S. Aithal*** \\ *Post Doctoral Research Scholar, Srinivas University, India and Associate Professor, Madan \\ Bhandari Memorial Academy Nepal, Urlabari3, Morang, Nepal \\ OrcidID: 0000-0003-2803-4918; Email: anjaymishra2000@ gmail.com \\ ** Visiting Faculty, Sanker Dev Campus, TU, Email; Kandeldeepak85@gmail.com \\ ***Professor, College of Management \& Commerce, Srinivas University, Mangalore, India \\ OrcidID: 0000-0002-4691-8736; E-mail: psaithal@gmail.com
}

\begin{abstract}
Purpose: Banking in Nepal is under the process of being systematized. Foreign aid is believed as key component for development in Nepal. This study aims to assess the impact, contribution and relationship of size, loans and deposit, inflation and capital on the profitability of the banks. Design/Methodology/Approach: Secondary data from 2013 to 2019 from seven commercial banks along with the survey as primary data were collected. The correlation and regression along with ratio analysis have been used to assure a contributory association among return on assets (ROA), return on equity (ROE) and net interest margin (NIM).

Findings/Result: The size of banks is in increasing trend. The decreasing trend of standard deviation showed that the size of Nepalese commercial banks has lower variation in the use of total assets as the year increases. There is a negative relation between ROA and ROE with loan ratio, deposit ratio and capital ratio, while there is positive relation with bank size and inflation. However, in case of NIM, bank size, loan ratio, deposit ratio and inflation exhibit a positive relation while the capital ratio shows the negative relationship with NIM. Majority of the respondents feel that the publication of financial reports is one of the major influencing factors of bank profitability.
\end{abstract}

Originality/Value: It is an empirical research to signify the contribution of Bank Size, Loan Ration, Deposit Ratio, Capital Ratio and Inflation as determinants of Profitability.

Paper Type: Analytical Business Research.

Keywords: ROA, ROE, NIM, Size, Trends

\section{INTRODUCTION :}

The profitability is a wide subject of study as its relation with performance is of great concern in the construction to all other industry including banking. It can be determined in terms of return on assets, return on equity (ROE), return on capital employed and net interest margin [1]. Size of bank, capital, loan, and deposit were independent variables for profitability. There exists a relationship between total assets and bank profitability. As the size (natural logarithm of total assets) of bank increases, return on assets decreases. This signifies that bank profitability also decreases because Return on Assets had a direct relation with bank profitability. This clearly indicated that it was not true that, only banks with the highest assets have high profitability. It was also examined that total deposits and total equity have inverse relationship with bank profitability. As a deposit of bank increases, return on Assets decreases. Similarly, as the capital of banks increases, return on Assets decreases. Since, there was a direct association between Return on Assets and profitability of the bank, it was clear those banks with highest total deposits and total equity does not possess the highest profitability [2]. Since banks with highest loan have the lowest Return on Assets in comparison to banks with the lowest loan, Loan had negative contribution to bank profitability. This clearly revealed that as loan ratio increases, return on assets decreases that means bank profitability also decreases. Similarly, return on equity and return on capital employed also have negative relation with size, capital, loan, and deposit. But net interest margin had positive relation with respect to size and capital, while a negative relation with loan and deposit. A country like Nepal, where banks are under process of growing to support the economy, which largely 
depends on foreign aid [3]. It is clear that bank performance determines profitability to support national infrastructure. So, a study assuring the same required.

\section{OBJECTIVES :}

The general objective of the study is to assess the impact, contribution and relationship of size, loans and deposit, inflation and capital on the profitability of the banks.

\section{LITERATURE REVIEW :}

Pokharel and Mishra (2020) [4] analyzed the financial performance of commercial banks using the concept of Aladwan, D. M. (2015) [5] in Nepal using financial ratios applicable in banking sectors to revealed that PCBL and SBL are well capitalized and they were complying with the directives of NRB. Total assets of SBL were riskier than that of PCBL as SBL used a higher portion of debt capital to finance the total assets than PCBL does. The standard deviation and coefficient of variation of SBL were $2.995 \%$ and $4.16 \%$ respectively and standard deviation and coefficient of PCBL were $3.47 \%$ and $4.84 \%$, respectively. It reveals that SBL had maintained its consistency comparing to PCBL. On the basis of ROE, it can be concluded that SBL had higher income earning capacity than PCBL from effectively mobilizing the shareholder's equity. Comparing two banks on the basis of total interest earned to total assets, it can be concluded that the capacity of utilizing total assets to generate interest income was highest in SBL as compared to that of PCBL. Both the sample banks have complied with the NRB's norms in the five consecutive years. Comparing two banks on the basis of $\mathrm{P} / \mathrm{E}$ ratio, it can be concluded that the mean ratio of SBL was higher than that of PCBL. But there was also a high inconsistency in earning of SBL as standard deviation and coefficient of variation were $11.89 \%$ and $56.89 \%$, respectively. Further ROA was positively correlated with all other ratios except for total operating expenses to total operating revenue ratio, it indicates that an increase in such ratio will lead to an increase in ROA. Similarly, ROE was positively correlated with Risk-weighted assets to total assets ratio, return on total deposit ratio, EPS, the liquid fund to total deposit ratio, which indicates that an increase in such ratio will lead to an increase in ROE.

Bhandari (2016) [6] had conducted similar to Davydenko, A [7] the study on financial performance analysis of Nepal SBI bank limited. in the framework of CAMEL with the objective to analyze the financial performance of Nepal SBI Bank Ltd with the coverage of vi years data of the bank. The bank's financial soundness is judged on the basis of some factors-capital adequacy, asset quality, and management soundness, earning quality, liquidity position and sensitivity to market risk. The study revealed that the capital fund ratio shows that NSBL had maintained adequate funds over the study period. The risk-based total capital ratio of NSBL showed that the total capital adequacy ratio of the bank was adequate and sufficient and showed that NSBL had met the requirement of NRB during the study period.

The ratio of past-due loans to total loan of NSBL showed that the quality of assets was strong. The percentage of substandard loan to total loan had implied that the quality of loan in the study period of the bank was strong from the perspective of substandard loan portion to total loan. The percentage of doubtful loan to total loans revealed that the quality of loan of the bank is strong. Percentage of loss loan to total loan is below 5percent in the study period indicates that the quality of assets is strong. The ratio of provision for substandard loan to total substandard loan was less than the 25 percent in the study period. This means that the bank has not made adequate provision for substandard loans as per the NRB guidelines. The ratio of provision for the doubtful loan to total doubtful loan shows that the bank had made adequate provision only in the year 2014/15 as per the NRB standard of 100 percent in the study period. It shows that the bank was trying to meet the NRB standard in recent years.

Mishra and Aithal (2020) referred a master's thesis of Tribhuvan University [8] where Hooshyari, N., \& Moghanloo, A. P. (2015) [9]. concept had been investigated the financial performance analysis of joint venture commercial banks in Nepal with objectives of analyzing profitability and liquidity. The result indicated that both banks have higher liquidity as compared to the normal standards. Likewise, the average cash reserve ratio of EBL is better than NABIL but both banks have maintained as directed by NRB standard. Similarly, EBL is most efficient so far as the matter of utilizing owners' equity to 
generate revenues was concerned regarding resource utilization. However, NPL of NABIL was more than NRB standard and weak condition as showing the non-performing loan. Hence, under the liquidity \& profitability analysis; EBL was a leading bank than NABIL by analyzing as explained financial indicators.

In an unpublished master's thesis applied concept of Ishfaq, M. J. (2015) [10]. had used annual general report of NBL and HBL from 2010/11 to 2014/15. The researcher had a panel data model while analyzing the data. With the use of ratio analysis of financial tools and arithmetic mean, coefficient of variation, coefficient of correlation and trend analysis the researcher analyzed the data and generate some results which are highlighted below: The liquidity position of HBL was found to be comparatively better than NBL. However, NBL had maintain better cash and bank balance to total deposit and cash and bank balance to current deposits ratios. HBL was more successful in on-balance sheet utilization as well as off balance sheet operation than that of NBL.HBL had a consistency in earning the profit and expenses on interest. HBL was successful in earning a higher profit even though with higher interest expenses, whereas NBL was average with respect to its own total assets and increasing total deposits than that of HBL. The correlation between the deposit and loan and advances for HBL was strongly positive as well as there was a significant relationship between them. Whereas for NBL, the correlation between total deposits and loan and advances was a highly positive but not significant relationship between them. The trend line of all sample banks was in increasing trend in case of a deposit, loan and advance and net profit. The trend values of total investment of HBL and NBL were in decreasing trend, which means that both banks had not properly utilized total deposit as investment to generate more net profit.

\section{RESEARCH METHODOLOGY :}

Table 1 shows list of commercial banks whose data collected from reports and survey and analyzed using financial and statistical like regression, correlation and descriptive statistical tools.

Table 1: Selection of banks along with study period 2013 to 2019 and equal 7 numbers of observations of each Bank.

\begin{tabular}{|l|}
\hline Commercial Banks \\
\hline Nabil Bank Limited \\
\hline Everest Bank Limited \\
\hline NIC Asia Bank Limited \\
\hline Nepal Investment Bank Limited \\
\hline Himalayan Bank Limited \\
\hline Nepal SBI Bank Limited \\
\hline Siddhartha Bank Limited \\
\hline
\end{tabular}

The dependent variable usually used in the study analysis of bank profits is a return on assets (ROA), return on equity (ROE) and net interest margin (NIM). Independent variables are usually arising from internal and external sources. Internal factors focus on bank-specific features i.e., size, capital, loan, and deposits, while external factor considers macroeconomic factor i.e., inflation. The figure shows those factors that determine profitability. 


\subsection{Research Framework :}

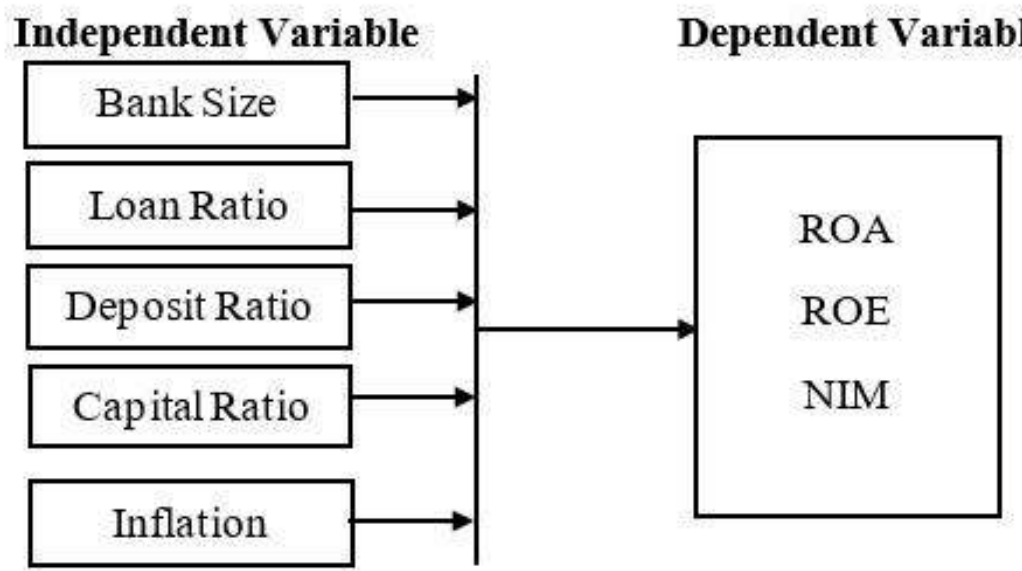

Fig.1 : Diagram of study variable

\section{RESULTS AND DISCUSSION :}

5.1 Expressing of Return on Assets (ROA) Analysis:

Table 2: ROA Description

\begin{tabular}{|l|l|l|l|l|l|l|l|l|l|c|}
\hline $\begin{array}{l}\text { Fiscal } \\
\text { Year }\end{array}$ & $\begin{array}{l}\text { LABI } \\
2013\end{array}$ & NIBL & HBL & EBL & NIC & NSBI & SBL & Mean & S.D. & C.V. \\
\hline 2014 & 2.57 & 2.62 & 1.51 & 2.21 & 2.20 & 1.50 & 0.55 & 1.95 & 0.76 & 39.21 \\
\hline 2015 & 1.76 & 1.80 & 1.31 & 1.57 & 1.09 & 1.64 & 1.42 & 1.51 & 0.24 & 15.80 \\
\hline 2016 & 2.15 & 1.96 & 1.92 & 1.52 & 1.45 & 1.59 & 1.65 & 1.75 & 0.24 & 13.84 \\
\hline 2017 & 2.51 & 2.00 & 2.01 & 1.57 & 1.77 & 1.56 & 1.53 & 1.85 & 0.33 & 17.72 \\
\hline 2018 & 2.47 & 2.12 & 1.57 & 3.58 & 1.32 & 1.97 & 1.46 & 2.07 & 0.72 & 34.78 \\
\hline 2019 & 2.11 & 1.73 & 2.08 & 6.28 & 0.18 & 1.94 & 1.47 & 2.25 & 1.76 & 77.95 \\
\hline Mean & 2.37 & 2.07 & 1.67 & 2.70 & 1.37 & 1.67 & 1.39 & - & - & - \\
\hline S.D. & 0.38 & 0.28 & 0.31 & 1.61 & 0.59 & 0.18 & 0.35 & - & - & - \\
\hline C.V. & 15.83 & 13.39 & 18.33 & 59.53 & 42.86 & 10.96 & 25.12 & - & - & - \\
\hline
\end{tabular}

Table 2 presents the result of return on assets of the sample banks. The average of this ratio are 2.37 percent, 2.07 percent, 1.67 percent, 2.70 percent, 1.37 percent, 1.67 percent and 1.39 percent for NABIL bank, NIBL bank, HBL bank, EBL bank, NIC bank, NSBI bank and SBL bank, respectively. This indicates that the ROA for NABIL bank, NIBL bank, HBL bank, EBL bank, NIC Asia bank, NSBI bank and SBL are good. Among them NABIL bank has more ROA. This seems that NABIL Bank has better profitable situation. Likewise, the standard deviation of the sample bank are 0.38 percent, 0.28 percent, 0.31 percent, 1.61 percent, 0.59 percent, 0.18 percent and 0.35 percent, respectively. 
According to coefficient of variation, NSBI bank is more uniformity which has slightly less CV i.e., 10.96 percent.

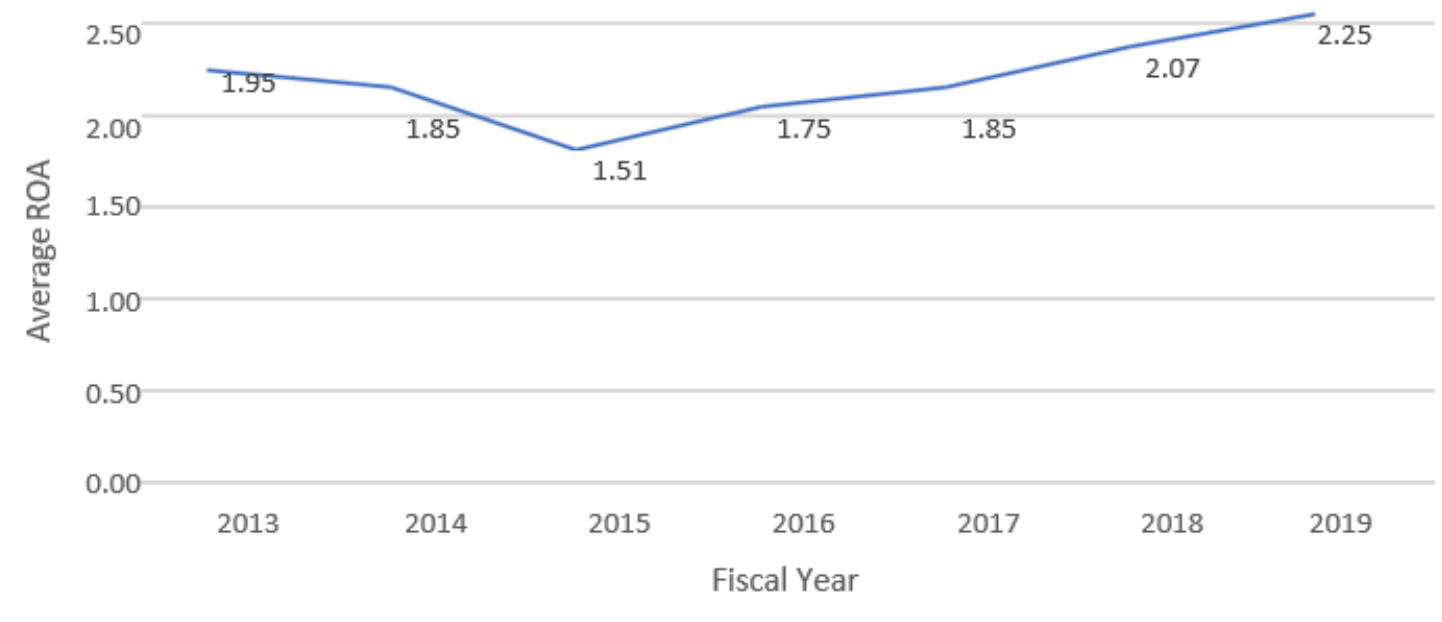

Fig. 2: Trends of Return on Assets

Figure 2 depicts that return on assets of the Nepalese commercial bank is reduced in fiscal year 2015 . The main cause of reducing such return on assets is earthquake. Afterwards, banking sector did lots of effort to increase return on assets. Thus, after 2016 return on assets of bank is increasing trend.

Return on Equity (ROE) Analysis:

Table 3 : Presenting of ROE

\begin{tabular}{|l|l|l|l|l|l|l|l|l|l|l|}
\hline $\begin{array}{c}\text { Fiscal } \\
\text { Year }\end{array}$ & NABIL & NIBL & HBL & EBL & NIC & NSBI & SBL & Mean & S.D. & C.V. \\
\hline 2013 & 72.85 & 46.21 & 32.54 & 76.57 & 22.93 & 36.75 & 25.01 & 44.70 & 20.29 & 45.41 \\
\hline 2014 & 63.46 & 40.67 & 28.81 & 72.48 & 17.07 & 30.17 & 36.73 & 41.34 & 18.33 & 44.33 \\
\hline 2015 & 44.05 & 30.92 & 24.67 & 57.40 & 12.48 & 25.08 & 10.08 & 29.24 & 15.59 & 53.32 \\
\hline 2016 & 45.59 & 29.29 & 33.17 & 37.56 & 13.50 & 25.20 & 17.19 & 28.78 & 10.42 & 36.20 \\
\hline 2017 & 21.64 & 29.31 & 26.87 & 23.64 & 14.14 & 14.84 & 18.80 & 21.32 & 5.34 & 25.06 \\
\hline 2018 & 19.34 & 14.68 & 13.16 & 32.16 & 11.44 & 15.80 & 13.87 & 17.21 & 6.52 & 37.87 \\
\hline 2019 & 18.28 & 12.55 & 17.28 & 41.53 & 2.56 & 16.19 & 15.04 & 17.63 & 10.91 & 61.88 \\
\hline Mean & 40.74 & 29.09 & 25.21 & 48.76 & 13.45 & 23.44 & 19.53 & & & \\
\hline S.D. & 20.39 & 11.41 & 6.98 & 18.88 & 5.69 & 7.68 & 8.23 & & & \\
\hline C.V. & 50.03 & 39.24 & 27.69 & 38.72 & 42.35 & 32.78 & 42.12 & & & \\
\hline
\end{tabular}

In Table 3, the average of this ratio are 40.74 percent, 29.09 percent, 25.21 percent, 48.76 percent, 13.45 
percent, 23.44 percent and 19.53 percent for NABIL bank, NIBL bank, HBL bank, EBL bank, NIC bank, NSBI bank and SBL bank, respectively. This indicates that the ROE for NABIL bank, NIBL bank, HBL bank, EBL bank, NIC Asia bank, NSBI bank and SBL are good. Among them NABIL bank has more ROE. This seems that NABIL Bank has better profitable situation. Likewise, the standard deviation of the sample bank are 20.39 percent, 11.41 percent, 6.98 percent, 18.88 percent, 5.69 percent, 7.68 percent and 8.23 percent, respectively. According to coefficient of variation, HBL bank is more uniformity which has slightly less CV i.e. 27.69 percent. It depicts that return on equity of the Nepalese commercial bank is reduced from fiscal year 2013to 2018. After 2018, return on equity is increasing slightly.

Describing of Net Interest Margin (NIM):

Table 4 : Presentation of NIM

\begin{tabular}{|l|r|r|r|r|r|r|r|r|r|r|}
\hline $\begin{array}{r}\text { Fiscal } \\
\text { Year }\end{array}$ & NABIL & NIBL & HBL & EBL & NIC & NSBI & SBL & \multicolumn{1}{l|}{$\begin{array}{l}\text { Nverage } \\
\text { NIM }\end{array}$} & S.D. & C.V. \\
\hline 2013 & 4.79 & 4.24 & 4.01 & 4.13 & 2.56 & 2.50 & 1.50 & 3.39 & 1.11 & 32.82 \\
\hline 2014 & 4.09 & 3.48 & 3.34 & 4.09 & 3.36 & 2.86 & 3.10 & 3.47 & 0.43 & 12.48 \\
\hline 2015 & 2.97 & 2.74 & 3.15 & 2.88 & 2.52 & 3.45 & 2.66 & 2.91 & 0.29 & 10.10 \\
\hline 2016 & 3.29 & 3.02 & 3.41 & 2.84 & 2.66 & 3.07 & 2.80 & 3.01 & 0.25 & 8.33 \\
\hline 2017 & 3.86 & 3.20 & 3.62 & 1.80 & 3.28 & 2.92 & 2.87 & 3.08 & 0.62 & 20.09 \\
\hline 2018 & 3.89 & 3.40 & 3.65 & 3.45 & 4.17 & 4.04 & 2.65 & 3.61 & 0.47 & 13.14 \\
\hline 2019 & 3.56 & 3.32 & 3.78 & 5.38 & 3.20 & 3.98 & 3.03 & 3.7495 & 0.7332 & 19.55 \\
\hline Mean & 3.78 & 3.34 & 3.57 & 3.51 & 3.11 & 3.26 & 2.66 & & & \\
\hline S.D. & 0.55 & 0.43 & 0.27 & 1.07 & 0.54 & 0.54 & 0.50 & & & \\
\hline C.V. & 14.44 & 12.98 & 7.52 & 30.50 & 17.55 & 16.60 & 18.69 & & & \\
\hline
\end{tabular}

Table 4 presents the result of net interest margin where the mean of this ratio are 3.78 percent, 3.34 percent, 3.57 percent, 3.51 percent, 3.11 percent, 3.26 percent and 2.66 percent for NABIL bank, NIBL bank, HBL bank, EBL bank, NIC bank, NSBI bank and SBL bank, respectively. This indicates that the NIM for NABIL bank has more margin due to more interest expenses.it depict that net interest margin reduces in 2015. In 2015, Nabil interest goes out rather than in.

\section{Analysis of Bank Size:}

Table 5 : Analysis of Bank Size

\begin{tabular}{|l|l|l|l|l|l|l|l|l|l|l|}
\hline $\begin{array}{c}\text { Fiscal } \\
\text { Year }\end{array}$ & NABIL & NIBL & HBL & EBL & NIC & NSBI & SBL & Mean & S.D. & C.V. \\
\hline 2013 & 4.8654 & 4.8642 & 4.7957 & 4.8240 & 4.6858 & 4.8115 & 4.8875 & 4.8192 & 0.0624 & 1.29 \\
\hline 2014 & 4.9557 & 4.9354 & 4.8734 & 4.8540 & 4.7280 & 4.7859 & 4.6390 & 4.8245 & 0.1055 & 2.19 \\
\hline 2015 & 5.0744 & 5.0363 & 4.9281 & 5.0001 & 4.7966 & 4.7731 & 4.7326 & 4.9059 & 0.1278 & 2.61 \\
\hline 2016 & 5.1184 & 5.1132 & 5.0053 & 5.0565 & 4.8667 & 4.8962 & 4.8815 & 4.9911 & 0.1015 & 2.03
\end{tabular}


International Journal of Case Studies in Business, IT, and Education (IJCSBE), ISSN: 2581-6942, Vol. 5, No. 1, May 2021

PUBLICATION

\begin{tabular}{|l|l|l|l|l|l|l|l|l|l|l|} 
& & & & & & & & & \\
\hline 2017 & 5.1584 & 5.1913 & 5.0354 & 5.0664 & 4.9196 & 4.9998 & 4.9618 & 5.0475 & 0.0922 & 1.83 \\
\hline 2018 & 5.2068 & 5.2353 & 5.0733 & 5.1608 & 5.0041 & 5.0109 & 5.1133 & 5.1149 & 0.0844 & 1.65 \\
\hline 2019 & 5.3035 & 5.2691 & 5.1243 & 5.0664 & 5.3379 & 5.0730 & 5.1876 & 5.1945 & 0.1029 & 1.98 \\
\hline Mean & 5.0975 & 5.0921 & 4.9765 & 5.0040 & 4.9055 & 4.9072 & 4.9148 & & & \\
\hline S.D. & 0.1379 & 0.1423 & 0.1077 & 0.1134 & 0.2035 & 0.1126 & 0.1801 & & & \\
\hline C.V. & 70.28 & 72.46 & 53.59 & 56.75 & 99.84 & 55.27 & 88.54 & & & \\
\hline
\end{tabular}

Table 5 presents the results of bank size (logarithm of total assets) of the sample banks. Increasing size allows banks to spread fixed costs over a greater asset base, thereby reducing their average costs. According to table above Nabil bank enables to spread fixed costs by reducing average costs. Small banks may be able to form stronger relationships with local businesses and customers than large banks, allowing them access to information useful in setting contact terms and making better credit underwriting. It states that in average samples banks are able to increase the total assets. Because of this bank are able to expand the branches at various locations.

Analysis of Loan Assets Ratio:

\begin{tabular}{|c|c|c|c|c|c|c|c|c|c|c|}
\hline $\begin{array}{l}\text { Fiscal } \\
\text { Year }\end{array}$ & NABIL & NIBL & HBL & EBL & NIC & NSBI & $\begin{array}{c}\text { SB } \\
\mathbf{L}\end{array}$ & $\begin{array}{l}\text { Average } \\
\text { LR }\end{array}$ & S.D. & C.V. \\
\hline 2013 & 63.22 & 65.21 & 65.71 & 66.29 & 66.46 & 44.43 & 30.74 & 57.44 & & \\
\hline 2014 & 60.57 & 62.03 & 62.17 & 67.81 & 69.77 & 57.76 & 64.26 & 63.48 & 3.85 & 6.07 \\
\hline 2015 & 55.19 & 62.26 & 65.40 & 55.34 & 67.15 & 65.24 & 68.68 & 62.75 & 5.07 & 8.08 \\
\hline 2016 & 57.94 & 67.04 & 68.17 & 60.51 & 79.45 & 57.75 & 74.14 & 66.43 & 7.70 & 11.59 \\
\hline 2017 & 62.41 & 68.67 & 71.34 & 67.19 & 86.92 & 61.85 & 74.63 & 70.43 & 7.95 & 11.28 \\
\hline 2018 & 70.58 & 70.29 & 74.41 & 65.04 & 11.93 & 70.58 & 67.67 & 61.50 & 20.41 & 33.19 \\
\hline 2019 & 63.39 & 6.84 & 73.76 & 66.34 & 65.50 & 71.32 & 59.20 & 58.05 & 21.38 & 36.83 \\
\hline Mean & 61.90 & 57.48 & 68.71 & 64.07 & 63.88 & 61.28 & 62.76 & - & 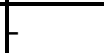 & 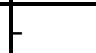 \\
\hline S.D. & 4.51 & 20.87 & 4.27 & 4.20 & 22.44 & 8.55 & 13.99 & - & & \\
\hline C.V. & 7.28 & 36.31 & 6.22 & 6.56 & 35.13 & 13.96 & 22.29 & - & & \\
\hline
\end{tabular}

Table 6 presents the average loan ratio of Nabil bank, NIBL bank, HBL, EBL, NIC Asia, NSBI and 
SBL. Among them HBL has to bear more risk since it provides more loan. The higher the loan ratio the bank liquidity is low and there arises default situation of bank. Thus, HBL generates more profit in terms of loan. However, HBL cannot provide interest to depositors. Likewise, the standard deviation of NABIL, NIBL, HBL, EBL, NIC, NSBI and SBI are 20.87 percent, 4.27 percent, 4.20 percent, 22.44 percent, 8.55 percent and 13.99 percent, respectively. According to coefficient of variation, HBL bank has more uniformity which has slightly less CV i.e., 6.22 percent. It depicts that in fiscal year 2015 and 2018 loan ratio reduces. The main causes of decrease in loan ratio might be of natural disaster like earthquake.

Table 7: Analysis of Deposit Ratio

\begin{tabular}{|l|l|l|l|l|l|l|l|l|l|l|}
\hline $\begin{array}{l}\text { Fiscal } \\
\text { Year }\end{array}$ & NABIL & NIBL & HBL & EBL & NIC & NSBI & SBL & $\begin{array}{l}\text { Average } \\
\text { DEPR }\end{array}$ & S.D. & C.V. \\
\hline 2013 & 86.73 & 85.34 & 84.94 & 86.57 & 82.69 & 43.82 & 36.79 & 72.41 & 20.43 & 28.21 \\
\hline 2014 & 83.49 & 85.67 & 86.56 & 86.92 & 84.15 & 57.98 & 81.32 & 80.87 & 9.52 & 11.77 \\
\hline 2015 & 87.82 & 83.36 & 86.77 & 83.06 & 85.42 & 87.15 & 82.81 & 85.20 & 1.96 & 2.30 \\
\hline 2016 & 83.95 & 8.34 & 86.28 & 82.31 & 94.45 & 82.82 & 85.30 & 74.78 & 27.38 & 36.62 \\
\hline 2017 & 82.56 & 80.89 & 85.60 & 81.62 & 104.35 & 80.86 & 84.42 & 85.76 & 7.77 & 9.06 \\
\hline 2018 & 84.47 & 81.64 & 84.25 & 64.73 & 149.81 & 82.18 & 78.38 & 89.35 & 25.47 & 28.51 \\
\hline 2019 & 81.02 & 8.19 & 84.93 & 81.62 & 82.95 & 82.23 & 65.08 & 69.43 & 25.74 & 37.08 \\
\hline Mean & 84.29 & 61.92 & 85.62 & 80.97 & 97.69 & 73.86 & 73.44 & - & - & - \\
\hline S.D. & 2.17 & 33.97 & 0.88 & 6.94 & 22.51 & 15.12 & 16.25 & & - & - \\
\hline C.V. & 2.57 & 54.87 & 1.03 & 8.58 & 23.04 & 20.47 & 22.13 & - & - & - \\
\hline
\end{tabular}

Table 7 presents the result of deposit ratio of the sample banks. The average of this ratio are 84.29 percent, 61.92 percent, 85.62 percent, 80.97 percent, 97.69 percent, 73.86 percent and 73.44 percent for NABIL bank, NIBL bank, HBL bank, EBL bank, NIC bank, NSBI bank and SBL bank, respectively. This indicates that the deposit ratio for NIC Asia bank is higher. Due to market capturing strategy NIC Asia is able to increase the deposit in the market. Likewise, the standard deviation of the sample bank are 2.17 percent, 33.97 percent, 0.88 percent, 6.94 percent, 22.51 percent, 15.12 percent and 16.25 percent, respectively. According to coefficient of variation, HBL bank has more uniformity which has slightly less CV i.e., 1.03 percent. It illustrates the trend of deposit of the sample bank. The deposit ratio is maximum in fiscal year 2018 i.e., 89.35 percent and thereafter deposit ratio falls.

\section{Analysis of Capital Ratio:}

Table 8 : Analysis of Capital Ratio

\begin{tabular}{|l|l|l|l|l|l|l|l|l|l|l|}
\hline $\begin{array}{l}\text { Fiscal } \\
\text { Year }\end{array}$ & NABIL & NIBL & HBL & EBL & NIC & NSBI & SBL & $\begin{array}{l}\text { Average } \\
\text { CAPR }\end{array}$ & S.D. & C.V. \\
\hline 2013 & 4.15 & 5.66 & 4.64 & 2.88 & 9.59 & 4.09 & 2.22 & 4.75 & 2.24 & 47.09 \\
\hline 2014 & 4.05 & 5.53 & 4.46 & 2.99 & 9.12 & 4.99 & 4.41 & 5.08 & 1.80 & 35.50 \\
\hline 2015 & 4.01 & 5.84 & 5.31 & 2.74 & 8.70 & 6.55 & 14.09 & 6.75 & 3.47 & 51.41 \\
\hline
\end{tabular}


International Journal of Case Studies in Business, IT, and Education (IJCSBE), ISSN: 2581-6942, Vol. 5, No. 1, May 2021

PUBLICATION

\begin{tabular}{|l|l|l|l|l|l|l|l|l|l|l|}
\hline 2016 & 4.71 & 6.71 & 5.78 & 4.04 & 10.75 & 6.32 & 9.59 & 6.84 & 2.29 & 33.42 \\
\hline 2017 & 11.60 & 6.84 & 7.48 & 6.64 & 12.53 & 10.54 & 8.13 & 9.11 & 2.23 & 24.49 \\
\hline 2018 & 12.79 & 14.47 & 11.94 & 11.14 & 11.56 & 12.48 & 10.55 & 12.13 & 1.19 & 9.77 \\
\hline 2019 & 11.53 & 13.76 & 12.01 & 15.13 & 6.86 & 11.96 & 9.76 & 11.57 & 2.49 & 21.49 \\
\hline Mean & 7.55 & 8.40 & 7.37 & 6.51 & 9.87 & 8.13 & 8.39 & - & - & - \\
\hline S.D. & 3.86 & 3.65 & 3.05 & 4.50 & 1.76 & 3.19 & 3.67 & - & - & - \\
\hline C.V. & 51.09 & 43.42 & 41.38 & 69.09 & 17.86 & 39.28 & 43.77 & - & - & - \\
\hline
\end{tabular}

Table 8 presents the result of capital ratio of the sample banks. The average of this ratio are 7.55 percent, 8.40 percent, 7.37 percent, 6.51 percent, 9.87 percent, 8.13 percent and 8.39 percent for NABIL bank, NIBL bank, HBL bank, EBL bank, NIC bank, NSBI bank and SBL bank, respectively. This indicates that the capital ratio for NIC Asia bank is higher. Due to large number of deposits NIC Asia is able to increase the capital in the market. Likewise, the standard deviation of the sample bank are 3.86 percent, 3.65 percent, 3.05 percent, 4.50 percent, 1.76 percent, 3.19 percent and 3.67 percent, respectively. According to coefficient of variation, NIC Asia bank has more uniformity which has slightly less CV i.e., 17.86 percent.

It depicts the trend of capital ratio from fiscal year 2013 to 2019. From 2013 to 2018, the capital ratio of sample bank is increasing. But in 2019 the capital ratio decreases.

\section{Analysis of Inflation:}

Table 9 : Analysis of Inflation

\begin{tabular}{|c|c|}
\hline Fiscal Year & Inflation (\%) \\
\hline 2013 & 9.87 \\
\hline 2014 & 9.04 \\
\hline 2015 & 7.21 \\
\hline 2016 & 9.93 \\
\hline 2017 & 4.45 \\
\hline 2018 & 4.15 \\
\hline 2019 & 4.64 \\
\hline
\end{tabular}

Source: www.statista.com

Table 9 depicts the inflate rate of Nepal during 2013 to 2019 with an average at 4.64 percent, a slight drop compared to the previous year. It inflation rate is maximum in fiscal year 2016. In the fiscal year 2015, 2017and 2018, the inflation rate position was below the trend line.

Table 10 : Descriptive Statistical Analysis for the period 2013 to 2019

\begin{tabular}{|c|c|c|c|c|c|}
\hline $\begin{array}{c}\text { Independent } \\
\text { Variable }\end{array}$ & $\begin{array}{c}\text { Sample } \\
\text { Banks }\end{array}$ & $\begin{array}{c}\text { Average } \\
\text { Min. Value }\end{array}$ & $\begin{array}{c}\text { Average } \\
\text { Max. Value }\end{array}$ & Mean Value & $\begin{array}{c}\text { Standard } \\
\text { Deviation }\end{array}$ \\
\hline BSIZE & 7 & 4.9055 & 5.0975 & 4.985371 & .0835265 \\
\hline LR & 7 & 57.48 & 68.71 & 62.8686 & 3.39359 \\
\hline DEPR & 7 & 61.92 & 97.69 & 79.6843 & 11.33422 \\
\hline CAPR & 7 & 6.51 & 9.87 & 8.0314 & 1.05186 \\
\hline INF & 7 & 4.15 & 9.93 & 7.0214 & 2.64258 \\
\hline
\end{tabular}


Table 10 shows the descriptive statistics- where the dependent variables used in the study are: ROA is Return on assets, ROE is return on equity, the independent variables are; BSIZE as size of banks, LR as loan ratio, DEPR as deposit ratio, CAPR as capital ratio, and INF as inflation.

For the sample banks in the study ROA ranges from minimum 1.37 percent to maximum 2.70 percent. In terms of ROE, the value ranges from minimum 13.45 percent to maximum 48.76 percent with average and std. deviation of 28.6029 and 012.27430 , respectively. In terms of NIM, the value ranges from minimum 2.66 percent to maximum 3.78 percent with average \& Std. deviation of 3.3186 and 0.36375 , respectively. Similarly, mean value of bank size, loan ratio, deposit ratio, capital ratio and inflation are 4.985371 percent, 62.8686 percent, 79.6843 percent 8.0314 percent and 7.0214 percent respectively.

\section{Correlation Analysis Between study variables:}

The variable used in the study such as bank size, loan ratio, deposit ratio, capital ratio and inflation, ROA, ROE and NIM are all calculated on ratio. We attempt to explain the relationship among these variables of 7 samples of commercial banks during the period 2013 through 2019.

Return on assets is positively associated with return on equity, net interest margin, bank size and inflation. The relationship is also statistically significant $1 \%$. However, for bank size the relationship is statically significant at 5\%. Similarly, returns on assets are negatively with loan ratio, deposit ratio and capital ratio, but the relationship is not statistically significant.

Table 11 : Correlation Matrix

\begin{tabular}{|l|l|l|l|l|l|l|l|l|}
\hline & ROA & ROE & NIM & BSIZE & LR & DEPR & CAPR & INF \\
\hline ROA & 1 & - & - & - & - & - & - & - \\
\hline ROE & $.981^{* *}$ & 1 & - & - & - & - & - & - \\
\hline NIM & $.702^{*}$ & $.674^{*}$ & 1 & - & - & - & - & - \\
\hline BSIZE & $.726^{*}$ & 0.662 & $.675^{*}$ & 1 & - & - & - & - \\
\hline LR & -0.181 & -0.065 & 0.147 & -0.389 & 1 & - & - & - \\
\hline DEPR & -0.180 & -0.159 & 0.169 & -0.343 & $.674^{*}$ & 1 & - & - \\
\hline CAPR & $-.754^{*}$ & $-.848^{* *}$ & -0.565 & -0.412 & -0.259 & 0.219 & 1 & - \\
\hline INF & $.907^{* *}$ & $.875^{* *}$ & $.750^{*}$ & $.902^{* *}$ & -0.126 & -0.176 & -0.665 & 1 \\
\hline
\end{tabular}

** and * shows association is significant at the level of $1 \& 5 \%$.

As the table 11, shows ROE is positively related with net interest margin at the level of $5 \%$ Significant. . On the other hand, returns on equity are negatively related with loan ratio, deposit ratio and capital ratio but the relationship is not statistically significant. The correlations among the different pairs of explanatory variables are also relatively lower though some of them are statistically significant. Among dependent variables, the highest correlation coefficient is accounted to be 0.702 between return on equity and net interest margin and that among independent variables, the highest association is observed to be 0.902 between bank size with inflation.

\section{Regression Analysis:}

Table 12 : Regression result of ROA (Linear Models, $n=49$ )

\begin{tabular}{|c|c|c|c|c|c|c|c|c|c|}
\hline \multirow[t]{2}{*}{ Models } & \multirow[t]{2}{*}{ Intercepts } & \multicolumn{5}{|c|}{ Regression Coefficient of } & \multirow{2}{*}{\begin{tabular}{|c} 
Adjuste \\
d \\
R SQ \\
\end{tabular}} & \multirow[t]{2}{*}{ SEE } & \multirow[t]{2}{*}{ F Value } \\
\hline & & $\overline{\text { BSIZE }}$ & LR & DEPR & CAPR & INF & & & \\
\hline 1 & -0.3326 & 0.0737 & & & & & -0.1811 & 0.0484 & 0.0802 \\
\hline & $(-0.2560) *$ & $(0.2832) * * *$ & & & & & & & \\
\hline 2 & 0.0496 & & -0.0190 & & & & -0.1719 & 0.482 & 0.1197 \\
\hline & $(1.1008)$ & & $(-0.3460)$ & & & & & & \\
\hline 3 & -0.0116 & & & 0.0600 & & & -0.1844 & 0.0484 & 0.0659 \\
\hline
\end{tabular}




\begin{tabular}{|r|c|c|c|c|c|c|c|c|c|} 
& $(-0.0632) * * *$ & & & $\begin{array}{c}(0.2566) \\
* * *\end{array}$ & & & & & \\
\hline 4 & 0.0433 & & & & -0.0361 & & -0.1507 & 0.0477 & 0.2143 \\
\hline & $(1.7384)$ & & & & $(-0.4629)$ & & & & \\
\hline 5 & -0.0212 & & & & & 0.8153 & 0.0572 & 0.0432 & 1.3640 \\
\hline & $(-0.4150)$ & & & & & $1.1680)$ & & & \\
\hline 6 & -0.4936 & 0.0990 & -0.0017 & 0.0567 & -0.0367 & - & -1.7688 & 0.0741 & 0.0418 \\
\hline & $(-0.1756) * *$ & $(0.1499)$ & $(-0.0031)$ & $(0.0451) * *$ & $(-0.0494)$ & - & - & - & - \\
\hline 7 & 7.5622 & -1.6530 & -0.4087 & 0.7791 & 0.4655 & 4.5679 & 0.9394 & 0.0110 & 19.5892 \\
\hline & $(8.0087)$ & $(-7.9232)$ & $(-4.4259)$ & $(3.8779)$ & $(3.8314)$ & $(9.5037)$ & - & - & - \\
\hline
\end{tabular}

$R O A=\beta_{0}+\beta_{1} * B S I Z E+\beta_{2} * D E P+\beta_{3} * L O A N+\beta_{4} * C A P+\beta_{5} * I N F$ with $t$-statistics where dependent variable is Return on Assets denoted as ROA and independent variables are; BSIZE as size of banks, $L R$ as loan ratio, DEPR as deposit ratio, CAPR as capital ratio and INF as inflation.

'*', '**' and '***' sign conforms that that $t$ - and F-statistics are significant at 1, 5 and $10 \%$ level respectively.

Table 12, reveals that higher loan ratio would lead to lower return on assets. Similarly, higher equity capital leads to poor return on assets. However, the beta coefficients are significant for liquidity only at 5 percent level of significance.

The beta coefficients are positive for bank size, deposit ratio and inflation. The result shows that higher bank size (logarithm of total assets) leads to higher return on assets. It also indicates that larger market share leads to higher return on assets. The results reveal that higher the inflation, higher would be return on assets, however, beta coefficients are significant at 5 percent level of significance for credit to total deposit ratio only.

The regression of bank specific and macro-economic specific factors on bank performance has been analyzed by defining bank performance in terms of return on equity also. The regression results are presented in below Table 12 The table indicates that beta coefficients are negative for loan ratio, capital ratio and inflation. It reveals that higher loan ratio would lead to lower return on equity. Similarly, higher capital ratio and higher inflation leads to poor return on equity. However, the beta coefficients are significant for liquidity only at 5 percent level of significance.

The beta coefficients are positive for bank size and deposit ratio. The result shows that higher bank size (logarithm of total assets) leads to higher return on equity. It also indicates that larger market share leads to higher return on equity. The results reveal that higher the bank deposit, higher would be return on equity, However, beta coefficients are significant at 5 percent level of significance for credit to total deposit ratio only.

Table 13: Regression Result of ROE (Linear Model, $\mathbf{n = 4 9 )}$

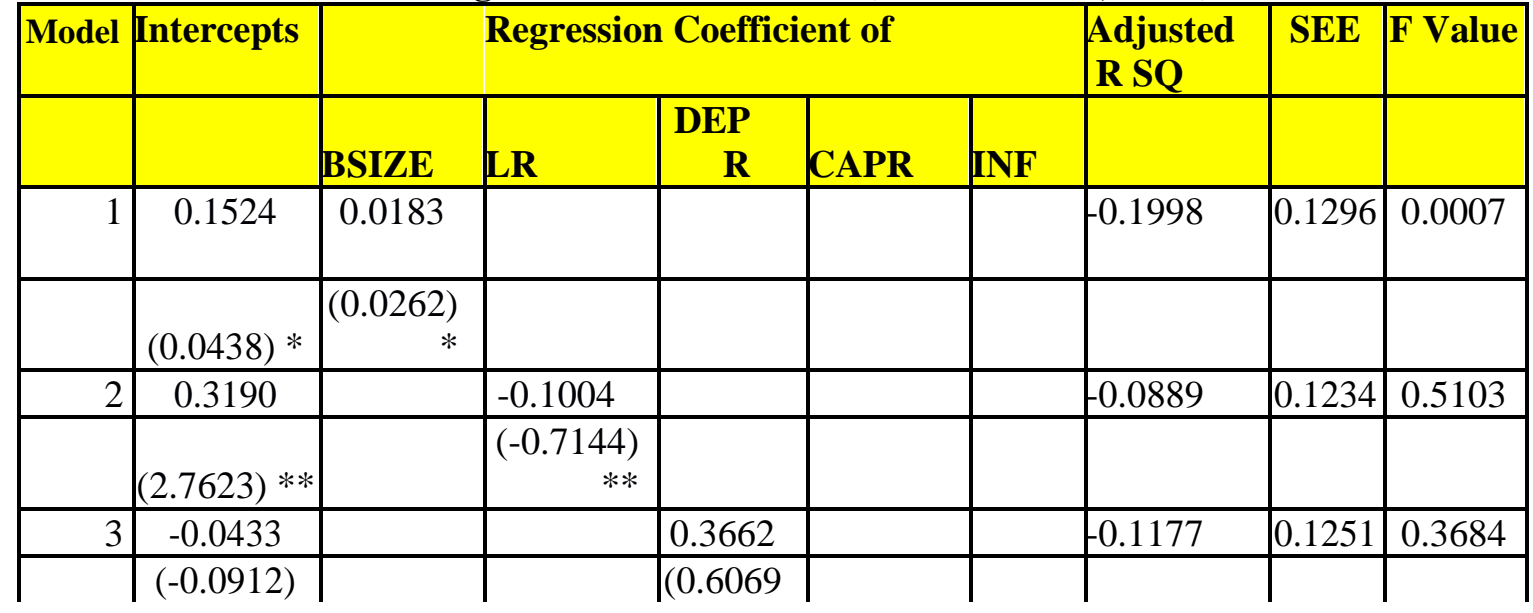




\begin{tabular}{|c|c|c|c|c|c|c|c|c|c|}
\hline 4 & $\begin{array}{c}* * \\
0.2789 \\
\end{array}$ & & & $\begin{array}{r}\text { ) } \\
* *{ }_{63} \\
\end{array}$ & -0.1610 & & -0.0615 & 0.1219 & 0.6526 \\
\hline & $\begin{array}{c}(4.3869) \\
* * *\end{array}$ & & & & $\begin{array}{c}(-0.8078) \\
* * *\end{array}$ & & & & \\
\hline 5 & 0.3375 & & & & & 1.3546 & -0.0995 & 0.1240 & 0.4572 \\
\hline & $(2.3007) * *$ & & & & & {$\left[\begin{array}{l}(- \\
0.6761 \\
* *\end{array}\right.$} & & & \\
\hline 6 & 5.4630 & -1.5290 & -1.7666 & 4.1618 & 2.1762 & & 0.5117 & 0.0827 & 2.5720 \\
\hline & $(1.7412) * *$ & $\begin{array}{l}(-2.0755) \\
* *\end{array}$ & $\begin{array}{l}(-2.8633) \\
* *\end{array}$ & $\begin{array}{l}(2.9674) \\
* *\end{array}$ & $\begin{array}{c}(2.6374) \\
* *\end{array}$ & & & & \\
\hline 7 & -3.5654 & 0.4345 & .1 .3104 & 3.3522 & 1.6136 & 5.1194 & 0.9974 & 0.0060 & $\begin{array}{l}467.207 \\
9\end{array}$ \\
\hline & $(-6.9050)$ & (3.8087) & $(-25.9502)$ & $(30.5124$ & (24.2870) & $\begin{array}{l}(- \\
19.477 \\
6)\end{array}$ & & & \\
\hline
\end{tabular}

Table 13 shows regression result of model one as: $R O E=\beta_{0}+\beta_{1} *$ BSIZE $+\beta_{2} * D E P+\beta_{3} *$ LOAN + $\beta_{4}{ }^{*} C A P+\beta_{5} *$ INF with $t$-statistics where dependent variable is Return on Assets denoted as ROA and independent variables are; BSIZE as size of banks, LR as loan ratio, DEPR as deposit ratio, CAPR as capital ratio and INF as inflation. '*', '**' and '***' sign conforms that that $t$ - and F-statistics are significant at 1, 5 and $10 \%$ level respectively.

The regression of bank specific and macro-economic specific factors on bank performance has been analyzed by defining bank performance in terms of net interest margin also. The regressions results are present. The beta coefficients are positive for bank size, loan ratio, deposit ratio and inflation. The result shows that higher bank size (logarithm of total assets) leads to higher interest margin. It also indicates that larger market share leads to higher interest margin. The results reveal that higher the deposit ratio and inflation, higher would be interest margin, however, beta coefficients are significant at 5 percent level of significance for credit to total deposit ratio only.

Table 14 : Regression Result of NIM (Linear Model, $\mathrm{n}=49$ )

$\therefore N I M=\beta_{0}+\beta_{1} * B S I Z E+\beta_{2} * D E P+\beta_{3} * L O A N+\beta_{4} * C A P+\beta_{5} * I N F$ with $t-$ Statics where Dependent variable is Return on Assets denoted as ROA and independent variables are; BSIZE as size of banks, $L R$ as loan ratio, DEPR as deposit ratio, CAPR as capital ratio and INF as inflation.

\begin{tabular}{|c|c|c|c|c|c|c|c|c|c|}
\hline \multirow[t]{2}{*}{ Models } & \multirow[t]{2}{*}{ Intercepts } & \multicolumn{5}{|c|}{$\begin{array}{c}\text { Regression } \\
\text { Coefficient of }\end{array}$} & \multirow[t]{2}{*}{\begin{tabular}{|c} 
Adjusted R \\
SQ \\
\end{tabular}} & \multirow[t]{2}{*}{ SEE } & \multirow[t]{2}{*}{$\begin{array}{c}\mathbf{F} \\
\text { value }\end{array}$} \\
\hline & & $\begin{array}{l}\text { BSIZ } \\
\text { E }\end{array}$ & LR & $\begin{array}{r}\text { DEP } \\
\mathbf{R}\end{array}$ & $\begin{array}{l}\text { CAP } \\
\mathbf{R}\end{array}$ & INF & & & \\
\hline 1 & -11.3390 & 2.9400 & & & & & 0.347 & 0.29395 & 4.188 \\
\hline & $(-1.5830) * *$ & $\begin{array}{r}(2.0460) \\
* *\end{array}$ & & & & & & & \\
\hline 2 & 2.3270 & & 0.0160 & & & & -0.174 & 0.39413 & 0.111 \\
\hline & $(0.7800) * *$ & & $\begin{array}{r}(0.3330) \\
* * \\
\end{array}$ & & & & & & \\
\hline 3 & 2.886 & & & $\begin{array}{r}0.005 \\
0 \\
\end{array}$ & & & -0.166 & 0.39274 & 0.147 \\
\hline & $(2.539) * *$ & & & $\begin{array}{c}(0.383 \\
0) \\
* *\end{array}$ & & & & & \\
\hline
\end{tabular}




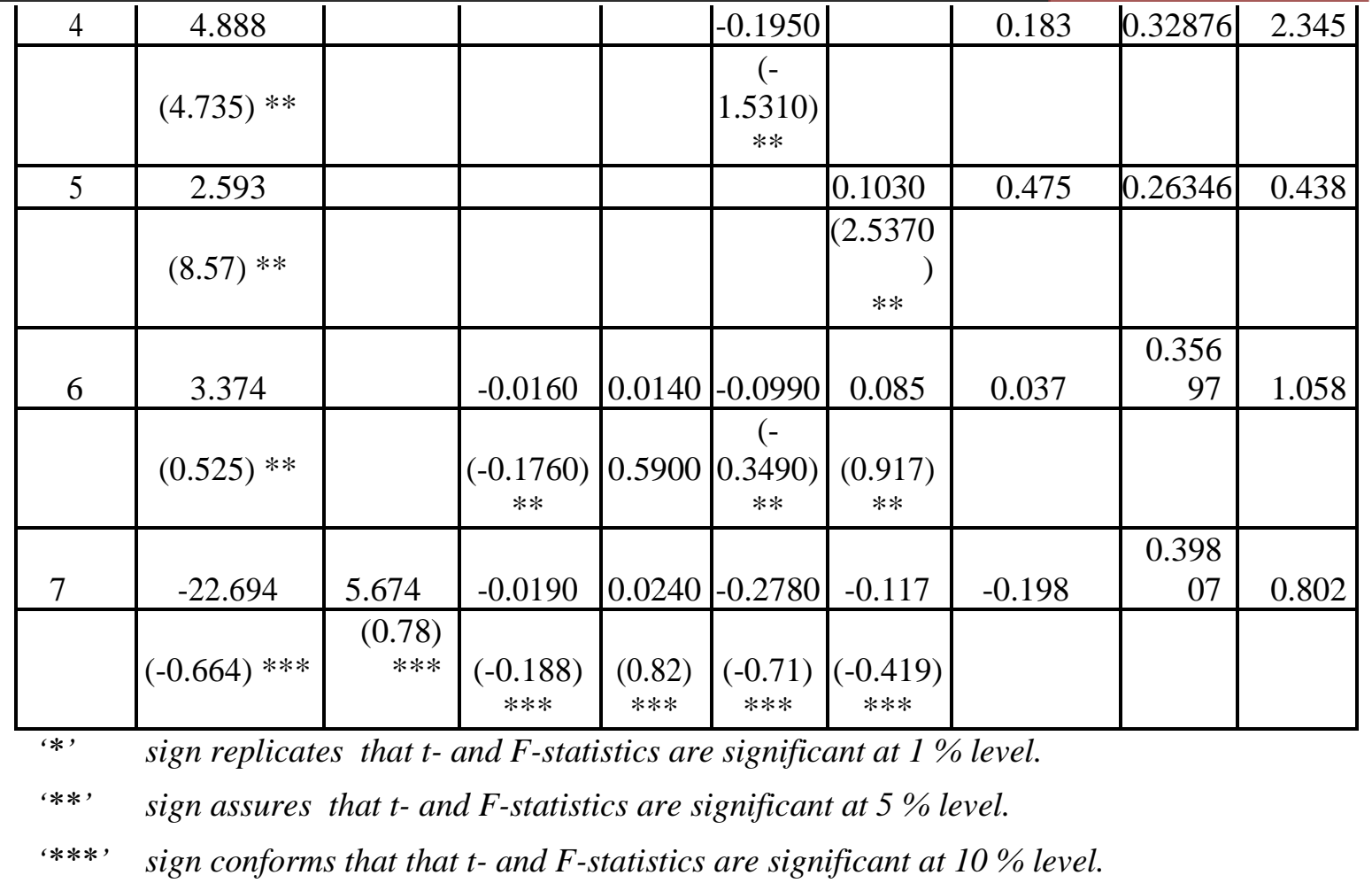

Questionnaire was done with 105 respondents at rate of $70 \%$ return, revealed that majority of respondents use company publication and websites (48.1\%), newspaper (22.2\%); and NEPSE publication and website $(13.6 \%)$ to get information regarding the profitability of banks. As the result shown, respondents think that investors in Nepalese commercial bank generally rely on company publication and website and Newspaper to generate required information on performance of banks. They also think that NEPSE publication and websites and SEBON publication and websites are important sources of information.

\section{Preference over Different Investment Alternatives:}

In order to know the bank preference for investments alternative, the respondents (investors and depositors) were asked to rank relative importance on bank's assets management on scale of ' 1 ' is most important to ' 4 ' is the least important.

From the survey results as shown in Table 15, Nepalese commercial banks are still emphasizing on balance sheet activities such as loan and advance; and off-balance sheet activities such as guarantees are most preferred and the investment in government securities and investment in corporate bonds and stocks receives less preferred among bank executives.

Table 15 : Survey Opinion on Bank’s Asset Management

This table contains the respondents' (investors and depositors) views on the survey questionnaire regarding bank assets management that increase the bank profitability in Nepalese commercial banks. Indications of 1 is the most important, next 2 is more important and so on. Also reported are the weighted mean value of ranking scores and overall ranks.

\begin{tabular}{|l|l|c|c|c|c|c|c|c|}
\hline S.N. & Items & \multicolumn{4}{|c|}{ Rank } & \multicolumn{1}{c|}{$\begin{array}{c}\text { Total } \\
\text { Responses }\end{array}$} & $\begin{array}{c}\text { Weighted } \\
\text { Mean }\end{array}$ & $\begin{array}{c}\text { Overall } \\
\text { Rank }\end{array}$ \\
\cline { 3 - 9 } & & $\mathbf{1}$ & $\mathbf{2}$ & $\mathbf{3}$ & $\mathbf{4}$ & 105 & 1.60 & I \\
\hline a. & $\begin{array}{l}\text { Loan } \\
\text { advances }\end{array}$ & 63 & 21 & 21 & 0 & 705 & 2.34 & III \\
\hline b. & $\begin{array}{l}\text { Investments } \\
\begin{array}{l}\text { in } \\
\text { government } \\
\text { securities }\end{array}\end{array}$ & 15 & 46 & 37 & 7 & 105 & \\
\hline
\end{tabular}


International Journal of Case Studies in Business, IT, and Education (IJCSBE), ISSN: 2581-6942, Vol. 5, No. 1, May 2021

\begin{tabular}{|l|l|l|l|l|l|l|l|l|} 
c. & $\begin{array}{l}\text { Investment } \\
\text { in corporate } \\
\text { bonds and } \\
\text { stocks }\end{array}$ & 9 & 52 & 13 & 31 & 105 & 2.63 & IV \\
\hline d. & $\begin{array}{l}\text { Guarantees } \\
\text { (LC, bid } \\
\text { bond, } \\
\text { performance } \\
\text { bond etc.) }\end{array}$ & 37 & 35 & 7 & 26 & 105 & 2.21 & II \\
\hline
\end{tabular}

Attitudes towards Factors Affecting Bank Profitability:

Source: Field Survey 2020

The survey results indicate (table 16) that loan ratio has the top most important factors that affects bank profitability and accordingly deposit ratio, size of bank, capital ratio and inflation got the second, third and fourth position respectively as bank-specific factors affecting bank profitability in Nepalese commercial banks. Inflation as macroeconomic variable got fifth position which affect bank profitability.

Table 16 : Survey Opinion on Factors Affecting Bank Profitability

This table contains the respondents' (investors and depositors) views on the survey questionnaire with regard of bank-specific factors to increase the bank profitability. Indications of 1 is the most important, next 2 is more important and so on.

\begin{tabular}{|l|l|c|c|c|c|c|c|c|c|}
\hline S. N. & Major & \multicolumn{9}{|c|}{ Rank } & Total & Weighted & $\begin{array}{c}\text { Overall } \\
\text { Rank }\end{array}$ \\
\cline { 3 - 10 } & Variables & $\mathbf{1}$ & $\mathbf{2}$ & $\mathbf{3}$ & $\mathbf{4}$ & $\mathbf{5}$ & Responses & Mean & Ran \\
\hline a. & Bank size & 40 & 25 & 7 & 2 & 31 & 105 & 2.61 & III \\
\hline b. & Loan ratio & 30 & 28 & 40 & 7 & 0 & 105 & 2.23 & I \\
\hline c. & Deposit ratio & 32 & 25 & 20 & 27 & 1 & 105 & 2.43 & II \\
\hline d. & Capital ratio & 14 & 22 & 19 & 44 & 6 & 105 & 3.06 & IV \\
\hline e. & Inflation & 12 & 20 & 33 & 2 & 38 & 105 & 3.32 & V \\
\hline
\end{tabular}

\section{Respondents on bank specific variable and macroeconomic variable:}

The survey also attempts to identify the perception of investors and bank depositors about the impact of bank specific factors on bank profitability in Nepalese commercial banks.

Table 17 : Factors Affecting Bank Profitability

\begin{tabular}{|l|c|c|c|c|c|c|c|c|}
\hline Statement & $\begin{array}{c}\text { Strong } \\
\text { Agree }\end{array}$ & Agree & Undecided & Disagree & $\begin{array}{l}\text { Strong } \\
\text { Disagree }\end{array}$ & Total & Mean & Overall \\
\hline $\begin{array}{l}\text { Profitability depends on } \\
\text { deposit }\end{array}$ & 25 & 22 & 14 & 26 & 18 & 105 & 2.90 & VI \\
\hline $\begin{array}{l}\text { Profitability depends on } \\
\text { Investment }\end{array}$ & 19 & 25 & 23 & 18 & 20 & 105 & 2.94 & IV \\
\hline $\begin{array}{l}\text { Higher Capital ratio } \\
\text { increases the profitability }\end{array}$ & 8 & 13 & 63 & 21 & 0 & 105 & 2.92 & V \\
\hline $\begin{array}{l}\text { Profitability is affected } \\
\text { by inflection }\end{array}$ & 0 & 28 & 32 & 45 & 0 & 105 & 3.16 & III \\
\hline $\begin{array}{l}\text { Profitability depends on } \\
\text { use of Total Assets }\end{array}$ & 14 & 7 & 38 & 32 & 14 & 105 & 3.24 & II \\
\hline $\begin{array}{l}\text { Profitability depends on } \\
\text { size of bank. }\end{array}$ & 9 & 19 & 19 & 2 & 32 & 105 & 3.50 & I \\
\hline
\end{tabular}

Table 17 show the relationship between several firm-specific variables and bank value. The mean 
score below three indicates disagreement and mean score above three indicates agreement. It also reports mean score, standard deviation and overall rank associated with each statement. It also reports mean score, standard deviation and overall rank associated with each statement.

The tabulated responses of respondents in Table 4.19 exhibits that respondents (investors/depositors) tend to most agree that bank profitability in Nepalese commercial banks depends on size of banks with mean value of 3.50. As evident from the table, respondents also perceived that profitability in commercial banks depends on the use of total assets. Bank profitability is also influenced by investment and capital ratio which is ranked as fourth and fifth important factors with mean score of 2.95 and 2.92 respectively.

\section{CONCLUSION :}

With respect to ROA, the analysis of the study reveals that EBL Bank has the highest profitability ratio whereas NIC Asia Bank has the lowest profit during the sample period. The average bank profitability in commercial banks for the study period is 1.89 in terms of ROA. In terms of variability, Nepal SBI bank has less variation in profitability whereas Everest bank has more variation in bank profitability. With respect to ROE, the analysis of the study reveals that EBL Bank has the highest profitability ratio whereas NIC Asia Bank has the lowest profit during the sample period. The average bank profitability in commercial banks for the study period is 28.60 in terms of ROE. In terms of variability, Himalayan bank has less variation in profitability whereas NIC Asia bank has more variation in bank profitability. With respect to NIM, the analysis of the study reveals that NIC Asia Bank has the highest profitability ratio due to less margin whereas Nabil Bank has the lowest profit during the sample period. The average bank profitability in commercial banks for the study period is 3.32 in terms of NIM. In terms of variability, HBL bank has less variation in profitability whereas EBL has more variation in bank profitability.

The survey results from the primary data analysis revealed that depositors and investors feel that higher loan ratio, deposit ratio, profitability ratio, capital ratio and stable inflation can increase profitability on banking sector. Publication of financial reports is one of major influencing factors of bank performance. SEBON publication and website, Information provided by website of private investment service providers is found as important source of information to analyze share price of banks.

\section{RECOMMENDATIONS :}

1. Bank profitability has strong positive relation with loan ratio and deposit ratio. Hence, Nepalese commercial banks have to pay special attention for the efficient and effective utilization of assets to increase profits and bank value.

2. Deposit has positive and significant relation with bank profitability in terms of total deposits to total assets. So, the Nepalese banks should examine the deposit ratio and should try to increase the size of deposits of the banks to improve bank performance.

3. The survey results indicated the most priority of banks for its investment/ lending is hydropower sector with the overall rank of first and accordingly manufacturing and processing, trading, insurance and hotel sectors have the second, third, fourth and fifth important priority sectors for investment/lending of Nepalese banks respectively.

4. This study has assumed linear relationship between bank profitability and explanatory variables. In emerging markets, it is expected that there exists non-linearity. The future Studies are should be conducted to test predictive power of explanatory variables.

\section{REFERENCES :}

[1] Chilwal K, Mishra A. K. (2018). Impact of Performance on profitability of small hydropower projects in Nepal. International Journal of Current Research, 10(1), 63918-63925.

[2] Abugamea, G. (2018). Determinants of banking sector profitability: Empirical evidence from Palestine. Journal of Islamin and Finance, 4(1), 7-15.

[3] Mishra, A. K., \& Aithal, P. S., (2021). Foreign Aid Movements in Nepal. International Journal of Management, Technology, and Social Sciences (IJMTS), 6(1), 142-161. DOI: https://doi.org/10.5281/zenodo.4677825. 
[4] Pokhrel, L., \& Mishra, A. K. (2020). The Dynamic Linkage Between Interest Rates and Stock Prices: An Application of ARDL Bound Test. NOLEGEIN Journal of Financial Planning and Management, 3(1), 27-35p. Available from: https://www.researchgate.net/publication/ 342077867_NOLEGEIN_Journal_of_Financial_Planning_and_Management_The_Dynamic_Lin kage_Between_Interest_Rates_and_Stock_Prices_An_Application_of_ARDL_Bound_Test [accessed May 11 2021].

[5] Aladwan, D. M. (2015). The impact of bank size on profitability: An empirical study on listed Jordanian commercial banks. European Scientific Journal, 11(34), 219-220.

[6] Bhandari, G. (2016). Financial performance analysis of Nepal SBI bank limited in the framework of CAMEL. An unpublished master's degree thesis submitted to faculty of management, Tribhuvan University. www.tu.edu.np

[7] Davydenko, A. (2011). Determinants of bank profitability in Ukraine. Undergraduate Economic Review, 7(1), 11-25.

[8] Mishra, A. K., \& Aithal P. S., (2021). Foreign Aid Contribution for the Development of Nepal. International Journal of Management, Technology, and Social Sciences (IJMTS), 6(1), 162-169. DOI: https://doi.org/10.5281/zenodo.4708643

[9] Hooshyari, N., \& Moghanloo, A. P. (2015). Evaluating The impact of inflation on Profitability of banks. Kuwait Chapter of Arabian Journal of Business and Management Review, 4(9), 21-22.

[10] Ishfaq, M. J. (2015). Bank profitability, inflation and cost efficiency: A case of Pakistani banks. International Journal of Business and Management Review, 3(1), 42-54. 